\title{
Carpal tunnel syndrome and workers' compensation: A cross-Canada comparison
}

\author{
Robyn J Watts MD, Kannin B Osei-Tutu MSc, Donald H Lalonde MD MSc FRCSC
}

RJ Watts, KB Osei-Tutu, DH Lalonde. Carpal tunnel syndrome and workers' compensation: A cross-Canada comparison. Can J Plast Surg 2003;11(4):199-202.

Carpal tunnel syndrome (CTS) is the source of substantial workers' compensation claims in industrialized countries. Its pathogenesis, however, continues to be questioned. The purpose of the present study was to assess the attitudes of Canadian plastic surgeons toward Workers' Compensation Board (WCB)-supported claims for CTS and to assess patterns of resource allocation across Canada.

Sixty-seven plastic surgeons were asked to read a clinical scenario and respond whether they would support a WCB claim for CTS. Provincial WCB offices were contacted and asked to provide statistics surrounding CTS claims for 1997 to 2001. Fifty-eight per cent (39 of 67) of surgeons surveyed felt that CTS should be covered as a WCB claim, while $42 \%$ (28 of 67) felt that it should not be covered by WCB. In British Columbia, 50\% (six of 12) of surgeons were in support of the claim compared to $92 \%$ (11 of 12) of those from Alberta, $55 \%$ (17 of 31 ) of those from the Central Provinces and $42 \%$ (five of 12) of those from the Maritime Provinces. Trends of resource allocation and number of CTS claims per year are presented for the individual provinces for 1997 to 2001.

An extensive literature review revealed that there is minimal to no evidence to support the view that CTS should be a compensated claim. As defined by the WCB of Canada, a compensated claim is one that "arises out of, and in the course of, employment and that results from causes and conditions peculiar to the trade, occupation or industry." The ambiguity in the beliefs of Canadian plastic surgeons in supporting CTS as a WCB claim reflects a situation where many of the decisions to cover CTS as a WCB claim are not evidence based.

Key Words: Carpal tunnel syndrome; Etiology; Repetitive strain; Workers' compensation

\section{Le syndrome du canal carpien et l'indemnisa- tion des accidentés du travail : Une comparai- son pancanadienne}

Le syndrome du canal carpien (SCC) est la source d'importantes réclamations d'indemnisations de la part des travailleurs des pays industrialisés. Sa pathogenèse continue toutefois d'être remise en question. La présente étude vise à évaluer les attitudes des plasticiens canadiens par rapport aux réclamations reliées au SCC auprès de la Commission de la santé et de la sécurité du travail (CSST) ainsi que les schèmes d'attribution des ressources au Canada.

Soixante-sept plasticiens ont été invités à lire un scénario clinique et à répondre s'ils soutiendraient une réclamation reliée au SCC auprès de la CSST. On a communiqué avec les bureaux de la CSST des provinces pour qu'ils fournissent des statistiques au sujet des réclamations reliées au SCC entre 1997 et 2001. Cinquante-huit pour cent (39 des 67) chirurgiens sondés pensaient que le SCC devrait être couvert par la CSST, tandis que $42 \%$ (28 des 67) d'entre eux pensaient qu'il ne devrait pas l'être. En Colombie-Britannique, $50 \%$ (six des 12) des plasticiens soutenaient la réclamation, par rapport à $92 \%(11$ des 12$)$ des plasticiens de l'Alberta, à $55 \%(17$ des 31$)$ de ceux des provinces centrales et à $42 \%$ (cinq des 12 ) de ceux des Maritimes. Les tendances d'attribution des ressources et le nombre de réclamations reliées au SCC par année sont présentés pour chacune des provinces entre 1997 et 2001

Une analyse bibliographique fouillée révèle qu'il existe peu de données probantes, sinon aucune, pour soutenir une réclamation reliée au SCC. Telle qu'elle est définie par la CSST du Canada, une indemnisation découle de l'emploi et résulte de causes et de troubles propres au métier, à l'emploi ou à l'industrie. L'ambiguïté des convictions des plasticiens canadiens quant au soutien d'une réclamation reliée au SCC auprès de la CSST reflète le fait que bon nombre des décisions pour que la CSST indemnise les cas de SCC ne sont pas fondées sur des faits probants.
Carpal tunnel syndrome (CTS) is well known to us all. As
plastic surgeons, we are confronted with this problem on
almost a daily basis. It is the most common peripheral entrap-
ment neuropathy. American data demonstrate an estimated one
million adults have CTS annually requiring medical treat-
ment. The estimated nonmedical costs including settlement
and disability average US $\$ 10,000$ per hand. Taking into
account medical costs, and indirect costs covered by patients
and families, the total cost varies from US $\$ 20,000$ to
US $\$ 100,000$ per person (1). Importantly, it is also the source of
substantial workers' compensation claims in industrialized
countries such as the United States, England and Canada. Its development within the industrial community has been recognized and monitored for some time (2). Its pathogenesis, however, continues to be questioned.

In attempting to ascertain the etiology(ies) of CTS, several investigators have studied the prevalence of CTS in general and occupational populations. Prevalence rates have been considered in different countries of the world. The data are equivocal. Whereas some data suggests higher occurrences of CTS in the workplace (3-5), recent investigations have found the incidence in workplace and general populations to be similar $(6,7)$. Werner et al (7) employed a cross-sectional design to study the prevalence of CTS and upper extremity tendonitis

Division of Plastic Surgery, Dalhousie University, Saint John Regional Hospital, Saint John, New Brunswick

Correspondence: Dr Donald H Lalonde, 705 Millidge Avenue, Saint John, New Brunswick E2K 2N7. Telephone 506-648-7950,

fax 506-652-8042, e-mail huzil@health.nb.ca 


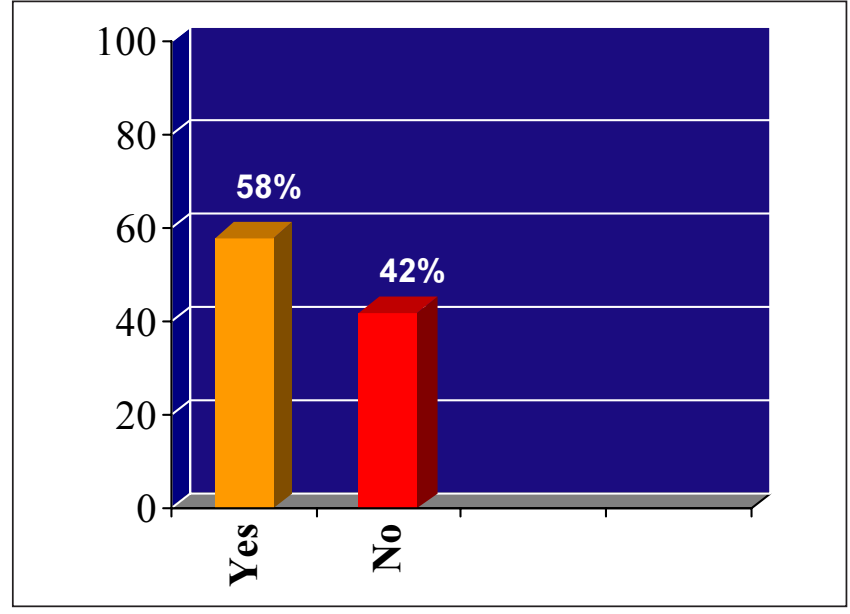

Figure 1) Results of the clinical scenario across Canada. Yes: Plastic surgeons would support a Workers' Compensation Board (WCB) compensated claim for carpal tunnel syndrome (CTS). No: Plastic surgeons would not support a WCB compensated claim for CTS

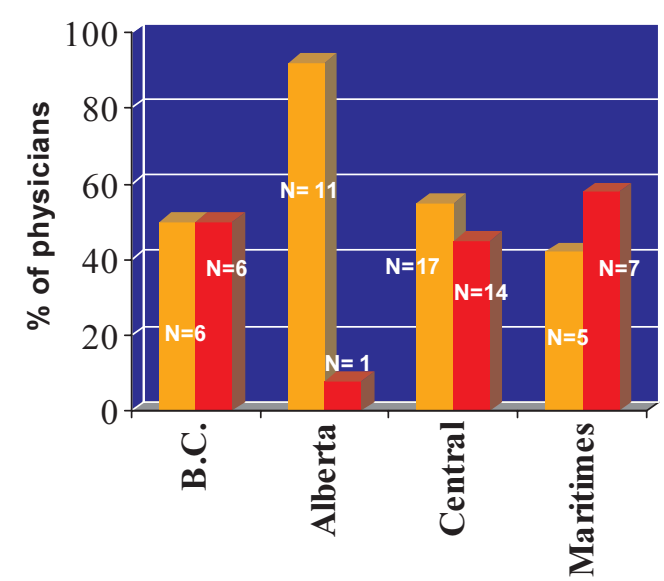

Figure 2) Results of the clinical scenario across the provinces. Yes: Plastic surgeons would support a Workers' Compensation Board (WCB) compensated claim for carpal tunnel syndrome (CTS). No: Plastic surgeons would not support a WCB compensated claim for CTS

among 305 dental hygienists. A prevalence of 3\% was found, nearly the same as in the general population.

Given these significant findings, in addition to the fact that no definite causal relation has been established between CTS and most occupations, we wanted to assess the appropriateness of support for and resource allocation of Workers' Compensation Board (WCB) claims for CTS in Canada.

The purpose of the present study was to assess the attitudes of Canadian plastic surgeons toward WCB-supported claims for CTS and to assess the patterns of resource allocation across Canada from 1997 to 2001.

\section{METHOD}

Sixty-seven plastic surgeons at the 2002 Canadian Society of Plastic Surgery meeting in Saint John, New Brunswick were surveyed and asked to respond "yes" or "no" to the following clinical scenario:
A 40-year-old secretary comes into your office with bilateral hand/arm symptoms consistent with severe carpal tunnel disease, which has been confirmed by electrodiagnostic studies and by her neurologist. You agree to do her surgery. She then asks you to support her claim to WCB because she states that her symptoms are aggravated by work. She has had these symptoms for two years and has worked in the same occupation for the past 10 years. Would you tell her that you would help her put her claim through?

In addition, individual provincial WCB offices were contacted by telephone or by e-mail and were asked to provide the following information: criteria required for CTS to be approved by WCB as a compensable claim; number of approved claims per year for 1997 to 2001; cost in compensation per year for 1997 to 2001; and average number of days off work for 1997 to 2001. An extensive literature review was completed by means of searching MEDLINE, PubMed and other internet databases, and published texts.

\section{RESULTS}

All plastic surgeons approached with the survey responded; therefore a $100 \%$ response rate was achieved. Fifty-eight per cent (39 of 67) of Canadian plastic surgeons surveyed thought that CTS should be covered as a WCB claim, while $42 \%$ of Canadian surgeons ( 28 of 67 ) thought that it should not be covered by WCB (Figure 1). Using a $\chi^{2}$ method of analysis, it was concluded that no statistically significant difference existed between the two different responses $(\mathrm{P}=0.18)$. In simple terms, roughly one-half of Canadian plastic surgeons believe that CTS should be covered by the WCB and one-half do not.

In British Columbia, 50\% (six of 12) of surgeons were in support of the claim, while $50 \%$ (six of 12) did not support the claim. Ninety-two per cent (11 of 12) of those from Alberta were in support of the claim while only $8 \%$ (one of 12) disagreed. Results from Manitoba $(n=1)$, Ontario $(n=26)$ and Quebec $(n=4)$ were compiled as the Central Provinces due to the low number of representative subjects. From the Central Provinces, 55\% (17 of 31) of surgeons thought that CTS should be compensated, while $45 \%$ (14 of 31) thought that CTS should not be compensated. Finally, 42\% (five of 12) of those surgeons from the Maritime Provinces including New Brunswick $(n=7)$, Nova Scotia $(n=4)$ and Prince Edward Island $(\mathrm{n}=1)$ thought that CTS should be covered as a WCB claim, while $58 \%$ (seven of 12) thought that it should not be covered by WCB (Figure 2). Using a $\chi^{2}$ analysis, a near statistically significant difference of $\mathrm{P}=0.06$ was observed between the provincial responses. This difference in provincial response can be attributed mostly to the aberrant results received from the province of Alberta. By removing Alberta from the calculation, no differences were observed in the responses from physicians in the British Columbia, Central and Maritime groups $(\mathrm{P}=0.741)$.

The results received from the individual provinces including the number of claims for CTS accepted by the WCB (Table 1), total cost of WCB claims for CTS (Table 2) and the average number of work days lost for CTS claims (Table 3) for years 1997 to 2001 are presented. The purpose of these results was to observe intraprovincial trends only. Cost comparisons could not be made between provinces because the data were not standardized and might have included costs accumulated 
from previous claims still being paid out during the specified dates. The results received from Nova Scotia included all those cases grouped as "diseases of the nervous system" and might include diseases other then CTS.

\section{DISCUSSION}

The present study revealed that roughly one-half of Canadian plastic surgeons believe that CTS should be covered by the WCB and one-half do not. A review of the literature described below reveals that there is little to no good evidence to support the notion that CTS should be covered by WCB. Therefore, the ambiguity of actual practice of what Canadian plastic surgeons support reflects a situation where many of the decisions to cover CTS as a WCB claim are not evidence based. In addition, the fact that there was a difference in the provincial treatment of this issue, particularly with respect to Alberta plastic surgeons, must mean that surgeons from different Canadian provinces are responding differentially to social and economic pressures that are unrelated to clinical evidence.

The WCB of Canada defines a compensable claim as one "that arises out of, and in the course of, employment and that results from causes and conditions peculiar to the trade, occupation or industry" (8). The central question remaining is whether CTS is actually caused by work, or whether it is a condition that would have occurred in the absence of work and is merely aggravated by work.

To date, a variety of conditions have been postulated to be associated with CTS (9). Inflammatory arthritis, Colles' fracture, amyloidosis, hypothyroidism, diabetes mellitus, acromegaly, and the use of corticosteroids and estrogens are among the known associated conditions $(10,11)$. Moreover, Atcheson et al (12) found up to one-third of CTS cases to be associated with medical conditions.

Because of the multifactorial causal nature of CTS, Falkiner and Myers (13) have questioned the circumstances under which CTS be considered work-related. In an extensive literature review, they identified the primary risk factors in the development of CTS as being a woman of menopausal age; obesity or lack of fitness; diabetes or family history of diabetes; osteoarthritis of the carpometacarpal joint of the thumb; smoking; and lifetime alcohol intake. Importantly, they concluded that work is less likely than demographic and diseaserelated variables to cause CTS and in most cases acts as the 'last straw' in CTS causation.
TABLE 1

Number of accepted claims for carpal tunnel syndrome by the Workers' Compensation Board per province for 1997-2001

\begin{tabular}{lrrrrr}
\hline Province & $\mathbf{1 9 9 7}$ & $\mathbf{1 9 9 8}$ & $\mathbf{1 9 9 9}$ & $\mathbf{2 0 0 0}$ & $\mathbf{2 0 0 1}$ \\
\hline British Columbia & 350 & 445 & 611 & 464 & 413 \\
Alberta & 381 & 383 & 364 & 464 & 442 \\
Saskatchewan & 92 & 135 & 131 & 166 & 187 \\
Manitoba & 221 & 238 & 240 & 243 & 171 \\
Ontario & 1212 & 1134 & 1246 & 1269 & 1083 \\
Quebec & $\mathrm{N} / \mathrm{A}$ & 306 & 263 & 341 & 263 \\
New Brunswick & 82 & 82 & 119 & 120 & 101 \\
Nova Scotia* & 166 & 143 & 189 & 199 & 167 \\
Prince Edward Island & 28 & 28 & 28 & 23 & 14 \\
Newfoundland & 33 & 32 & 55 & 50 & 36 \\
Northwest Territories/Yukon & 21 & 17 & 14 & 17 & 26 \\
\hline
\end{tabular}

*Includes carpal tunnel syndrome under category of "diseases of the nervous system". N/A Not available

Even more compelling are the recent findings by Hakim et al (14) who explored the genetic component of CTS in monozygotic and dizygotic female twins. They found up to one-half of the liability of CTS in women is genetically determined, and this appears to be the single strongest risk factor after controlling for age, body mass index, physical activities and horomonal/reproductive factors.

Studies commonly cited that support CTS as a work-related disorder have been fraught with flaws. The use of inconsistent diagnostic criteria is common. Because no gold-standard diagnostic test exists for the diagnosis of CTS, some investigators have simply relied on the subjective reports of patients without taking into account physical findings or electrodiagnostic studies. Other studies have failed to consider exposure from nonoccupational activities or failed to take into account confounding biologic variables such as age, sex and medical conditions known to be associated with the development of CTS (15-17). Vender at al (18) assessed 52 articles surrounding work and CTS and found that only 14 articles met basics diagnostic criteria for CTS. Of those 14 articles, five were discounted because they included only descriptive data, while the remaining nine were excluded due to flawed research design. Of the 52 articles reviewed, not one could confidently support a relation between work and CTS.

Nevertheless, there has been some support in some investigations of a higher incidence of CTS with repetitive, heavy load activities in cold temperature surroundings. This has been

TABLE 2

Total cost of claims for carpal tunnel syndrome paid out by the Workers' Compensation Board per province for 1997-2001

\begin{tabular}{|c|c|c|c|c|c|}
\hline Province & 1997 & 1998 & 1999 & 2000 & 2001 \\
\hline British Columbia & $4,719,591$ & $6,104,980$ & $9,465,349$ & $8,269,326$ & $11,145,319$ \\
\hline Alberta & $6,679,930$ & $8,771,912$ & $5,942,442$ & $9,079,154$ & $6,143,258$ \\
\hline Saskatchewan & 937,170 & $2,013,695$ & $1,886,949$ & $2,012,144$ & $1,977,800$ \\
\hline Manitoba & $1,879,478$ & $2,893,514$ & $2,221,793$ & $1,846,898$ & 987,443 \\
\hline Ontario & $20,505,083$ & $17,692,305$ & $18,791,738$ & $15,346,306$ & $9,609,676$ \\
\hline Quebec & N/A & $1,586,916$ & $1,179,818$ & $1,758,196$ & $1,581,419$ \\
\hline New Brunswick & 693,697 & $1,296,737$ & $1,436,926$ & $1,026,140$ & 885,603 \\
\hline Nova Scotia* & 109,203 & 113,799 & 251,790 & 229,519 & 216,737 \\
\hline Prince Edward Island & 39,529 & 118,021 & 129,219 & 161,022 & 94,409 \\
\hline Newfoundland & 407,254 & 424,679 & 634,449 & 609,904 & 467,357 \\
\hline Northwest Territories/Yukon & 443,900 & 36,648 & 218,694 & 75,131 & 171,748 \\
\hline
\end{tabular}

*Includes carpal tunnel syndrome under the category of "diseases of the nervous system". N/A Not available 


\begin{tabular}{|c|c|c|c|c|c|}
\hline Province & 1997 & 1998 & 1999 & 2000 & 2001 \\
\hline British Columbia & 110 & 112 & 119 & 149 & 154 \\
\hline Alberta & 96 & 126 & 108 & 105 & 88 \\
\hline Saskatchewan & 107 & 141 & 141 & 111 & 105 \\
\hline Manitoba & 167 & 179 & 149 & 113 & 70 \\
\hline Ontario & 108 & 160 & 154 & 127 & 96 \\
\hline Quebec & $N / A$ & 104 & 92 & 106 & 115 \\
\hline New Brunswick & 58 & 90 & 86 & 96 & 82 \\
\hline Nova Scotia* & 30 & 28 & 57 & 30 & 25 \\
\hline Prince Edward Island & 142 & 54 & 88 & 99 & 36 \\
\hline Newfoundland & 173 & 158 & 123 & 134 & 153 \\
\hline Northwest Territories/Yukon & N/A & N/A & $\mathrm{N} / \mathrm{A}$ & N/A & $N / A$ \\
\hline
\end{tabular}

*Includes carpal tunnel syndrome under the category of "wrist sprains \& strains". N/A Not available

demonstrated in slaughter house workers and meat packers $(3,19)$. However, as for the majority of common repetitive tasks, such as grocery handling, computer processing and assembly work, no definite causal relation between work and CTS has been identified.

It is interesting to note that American data demonstrates no change in the prevalence of CTS over the past decade in comparison to the steady decline seen in all other work-related injuries. This is despite substantial expensive ergonomic workplace alterations and in some instances workplace closures (13). In fact, median days off work are also highest for CTS: 27 compared to 20 for fractures and 18 for amputations with a mean time off work for all injuries of 6 days (20).

Furthermore, workers' compensation for CTS has been found to negatively affect surgical outcome. In a prospective study of

\section{REFERENCES}

1. Szabo RM. Carpal tunnel syndrome as a repetitive motion disorder. Clin Orthop 1998;351:78-89.

2. Ireland D. Australian repetition strain injury phenomenon. Clin Orthop 1998;351:63-73.

3. Gorsche RG, Wiley JP, Renger RF, Brant RF, Gemer TY, Sasyniuk TM. Prevalence and incidence of carpal tunnel syndrome in meat packing plant. Occup Environ Med 1999;56:416-22.

4. Roquelaure Y, Mariel J, Dano C, Fanello S, Penneau-Fontbonne D. Prevalence, incidence and risk factors of carpal tunnel syndrome in a large footwear factory. Int J Occup Med Environ Health 2001;14:357-67.

5. Stevens JC, Sun S, Beard CM, O'Fallon WM, Kurland LT. Carpal tunnel syndrome in Rochester, Minnesota, 1961-1980. Neurology 1988;38:134-8

6. Stevens JC, Witt JC, Smith BE, Weaver AL. The frequency of carpal tunnel syndrome in computer users at a medical facility. Neurology 2001;56:1568-70

7. Werner RA, Hamann C, Franzblau A, Rodgers PA. Prevalence of carpal tunnel syndrome and upper extremity tendonitis among dental hygienists. J Dent Hyg 2002;76:126-32.

8. Worker's Compensation Act. 1994-95, c. 10, s.1.

9. Katz JN, Simmons BP. Clinical practice. Carpal tunnel syndrome. N Engl J Med 2001;346:1807-12

10. Solomon DH, Katz JN, Bahn R, Mogun H, Avorn J. Nonoccupational risk factors for carpal tunnel syndrome. J Gen Intern Med 1999;14:310-4.

11. Stevens JC, Beard CM, O'Fallon WM, Kurland LT. Conditions associated with carpal tunnel syndrome. Mayo Clin Proc 1992;67:541-8

12. Atcheson SG, Ward JR, Lowe W. Concurrent medical disease in work-related carpal tunnel syndrome. Arch Intern Med 1998;158:1506-12.

13. Falkiner S, Myers $S$. When exactly can carpal tunnel syndrome be considered work related? ANZ J Surg 2002;72:204-9.
275 patients, Bednar et al (21) showed that patients receiving compensation returned to work less frequently, returned to modified duties more often and were off work longer with an average of 8.25 months in one compensated group versus 1.81 months in the group not receiving compensation. In addition, they concluded that compensated patients present a greater cost to the health care system because they required nearly twice the number of postoperative visits ( 8.5 versus 4.4 ) and a significantly greater number of months of postoperative therapy.

It is our belief that compression of the median nerve gradually increases in the carpal tunnel over time. As such, a patient initially progresses from being asymptomatic, to intermittently symptomatic, and finally to a constant symptomatic state as there is increasingly less room in the tunnel for the nerve. We also believe that although the slight increase in edema generated by work activity may be enough to transform an asymptomatic patient into a symptomatic one, it is very likely that that patient would have eventually become symptomatic with or without work-related activities. We believe that CTS is an anatomic problem generated by a relative lack of room for the nerve in the tunnel caused by a change in the volume of either the tunnel or the nerve.

\section{CONCLUSION}

An extensive literature review has revealed that there is minimal to no evidence to support the view that CTS should be a compensated claim. As defined by the WCB of Canada, a compensable claim is one that "arises out of, and in the course of, employment and that results from causes and conditions peculiar to the trade, occupation or injury". The ambiguity in the beliefs of Canadian plastic surgeons in supporting CTS as a WCB claim reflects a situation in which many of the decisions to cover CTS as a WCB claim are not evidence based.

14. Hakim AJ, Cherkas L, El Zayat S, MacGregor AJ, Spector TD. The genetic contribution to carpal tunnel syndrome in women: A twin study. Arthritis Rheum 2002;47:275-9.

15. Blanc PD, Faucet J, Kennedy JJ, Cisternas M, Yelin E. Self reported carpal tunnel syndrome: Predictors of work disability from the National Health Interview Survey Occupational Health Supplement. Am. J Occup Environ Med 1996;30:362-8.

16. Margolis W, Kraus JF. The prevalence of carpal tunnel symptoms in female supermarket checkers. J Occup Environ Med 1987;29:953-6.

17. Tanaka S, Wild D, Cameron LL, Freund E. Prevalence and work relatedness of self-reported carpal tunnel syndrome amongst United States workers: Analysis of the occupational health supplement data of the 1988 National Health Interview Survey. Am J Ind Med 1995;27:451-70.

18. Vender MI, Kasdan ML, Truppa KL. Upper extremity disorders: A literature review to determine work relatedness. J Hand Surg (Am) 1995:20A:534-41.

19. Frost P, Andersoen JV, Nielsen VK. Occurrence of carpal tunnel syndrome among slaughterhouse workers. Scand J Work Environ Health 1998;24:285-92.

20. Bureau of Labour Statistics. Case and demo news release: Lost worktime injuries and illnesses 2000 (on-line). <http://www.bls.gov /iif/oshwc/osh/case/osnr0015.pdf> (Version current at November 20, 2003).

21. Bednar JM, Baesher-Griffith P, Osterman AE. Worker's compensation: Effect of state law on treatment cost and work status. Clin Orthop 1998;351:74-7.

22. Herbert R, Janeway K, Schechter C. Carpal tunnel syndrome and worker's compensation among occupational clinic population in New York State. Am J Ind Med 1999;35:3335-42.

23. Katz JN, Lew RA, Bessette L, et al. Prevalence and predictors of long-term work disability due to carpal tunnel syndrome. Am J Ind Med 1998;33:543-50. 